Informatika i sistemy upravleniya. - 2018. - No. 1(55). - P. 42-50.

Devyatisilny A.S. (devyatis@dvo.ru), Shurygin A.V.

Institute of Automation and Control Processes

\title{
MATHEMATICAL MODELS OF TRAJECTORY PARAMETERS OF MOBILE OBJECTS FOR EMBEDDED GLONASS SYSTEMS
}

The article is devoted to the problem of expanding the on-board GLONASS. It presents a mathematical model of the corresponding inverse trajectory problem, describes the technology, covers a research, and proposes procedures for increasing the solvability of the problem under the finite accuracy of measurement and numeration in a computing environment. To solve the problem, we proposed a neural-like algorithm of the Kalman type. The results of computational experiments are also presented here.

Keywords: navigation satellite system, GLONASS, inverse trajectory problem, model, motion, velocity, neural-like algorithm.

DOI: $10.22250 /$ isu.2018.55.42-50

\section{For citation:}

Devyatisilny A.S., Shurygin A.V. MATHEMATICAL MODELS OF TRAJECTORY PARAMETERS OF MOBILE OBJECTS FOR EMBEDDED GLONASS SYSTEMS // Informatika i sistemy upravleniya. - 2018. - No. 1(55). - P. 42-50. 